\title{
Soil nematode abundances were increased by an incremental nutrient input in a paddy-upland rotation system
}

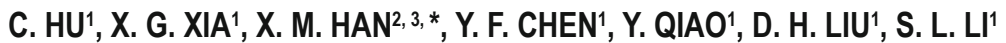

\begin{abstract}
${ }^{1}$ Institute of Plant Protection and Soil Fertilizer, Hubei Academy of Agricultural Sciences, Key Laboratory of Fertilizer Resource Utilization in Wastes, Ministry of Agriculture, Wuhan 430064, P. R. China; ${ }^{2 *}$ School of Life Science and Technology, Nanyang Normal University, Nanyang, 473061, P. R. China, E-mail: hanxuemei916@163.com; ${ }^{3}$ Collaborative Innovation Center of Water Security for Water Source Region of Mid-line of South-to-North Diversion Project, Henan Province, Nanyang, 473061, P. R. China
\end{abstract}

Article info

Received January 12, 2018 Accepted June 14, 2018

\begin{abstract}
Summary
To study the effect of fertilization on soil nematode communities in a paddy-upland rotation system, an ongoing thirty-three years long-term fertilizer experiment is conducted which includes seven treatments; an unfertilized treatment (control), nitrogen $(\mathrm{N})$, phosphorus $(\mathrm{P})$, potassium $(\mathrm{K})$ fertilizer treatments (N, NP, NPK) and organic manure (M) combined with chemical fertilizer treatments (MN, MNP, and MNPK). The soil nematode community structure and crop yields were determined in 2012 and 2013. Overall total nematode abundance was increased by an incremental nutrient input both in the rice and wheat fields. Total number of nematode was $1.25-2.37$ times greater in the rice field and was $1.08-2.97$ times greater in wheat field in the fertilization treatments than in the unfertilized treatment. Soil free-living nematode abundances was significantly $(P<0.001)$ increased in organic manure combined with chemical fertilizer treatments in rice field. Fungi-feeders and plant-feeding nematodes abundances were not significantly different among treatments in rice and wheat fields. Omnivorous and predatory nematodes were the most dominant groups in the present study. Omnivores, predators and Prodorylaimus abundances were significantly $(P<0.05)$ higher in organic manure combined with NPK fertilizer treatments than in chemical fertilizer alone and unfertilized treatments both in rice and wheat fields. Stepwise regressions revealed that soil free-living nematodes were significant predictors of rice grain yields $\left(R^{2}=0.56, P<0.001\right)$ and omnivorous and predatory nematodes were significant predictors of the wheat grain yield $\left(R^{2}=0.89, P<0.001\right)$. Therefore, long-term application of organic manure combined with chemical fertilizer could increase nematode abundances and crop yields. Organic manure combined with chemical fertilizer application was recommended in agricultural ecosystem.
\end{abstract}

Keywords: soil nematode community; trophic group; prodorylaimus; crop yields; long-term fertilizer experiment

\section{Introduction}

Maintaining sustainable soil utilization in developing countries is essential to supply the demand for food grain production. However, steady crop yields cannot be maintained without the application of some soil amendments (Gruzdeva et al., 2007). Long-term and large numbers of chemical fertilizer applications have led to the loss of soil fertility, a reduction in soil biodiversity, and polluted farm products (Singh et al., 2016; Ding et al., 2017). Therefore, the application of organic fertilizer has come under consideration. The benefits of long-term manure application to soil include better tilth, improved water-holding capacity and cation exchange capa-

\footnotetext{
$\bar{*}$ - corresponding author
} 
city, moderated soil temperature, enhanced crop performance, and increased soil organic matter and biological fertility (McSorley \& Gallaher, 1997). Accordingly, soil fertility and crop yields are increased and good physical or chemical soil properties and biological communities are maintained. However, the long-term application of chemical fertilizers leads to soil hardening, weak aeration, and weak biological activity (Hopkins \& Shiel, 1996).

Paddy rice-upland wheat crop rotation systems are one of the largest agricultural production systems in the world, mainly distributed in southern and eastern Asia (Brar et al., 2013). The 13.5 million hectares were in South Asia, and the other 10.5 million hectares are in South China, widely disseminated throughout the provinces of Jiangsu, Zhejiang, Hubei, Guizhou, Yunnan, Sichuan and Anhui, etc. (Hu et al., 2015). This area accounts for roughly half of the total rice cultivated area in China. Therefore, the protection of the soil environment in the rice-wheat crop system is crucial for the maintenance of sustainable crop yields and to ensure China's food security (Zhang et al., 2016).

Long-term field experiments are indispensable sources of knowledge and provide a tool for examining soil environment changes (Debreczeni \& Körschens, 2003). Furthermore, long-term fertilizer experiments could reflect the influence of fertilizer benefit, crop growth and soil environment due to annual changes in climate (Miao et al., 2011; Wei et al., 2016). Some information could be gained regarding sustainable agriculture and humanity's influence on the soil fertility, landscape and agricultural environment (Diacono \& Montemurro, 2010; Miles \& Brown, 2011; Peterson et al., 2012; Geisseler \& Scow, 2014).

Soil free-living nematode communities are known to be sensitive to agricultural management practices such as fertilization, irrigation, and tillage (Porazinska et al., 1999; Zhang et al., 2017a). Furthermore, soil nematodes can be placed into at least five functional or trophic groups. They occupy a central position in the soil detrital food web and play a crucial role in soil organic-matter decomposition, plant-nutrient mineralization, and nutrient cycling (Neher, 2001). Therefore, soil nematode diversity, species composition, trophic group, and biomass may be useful bioindicators for monitoring soil environmental changes (Gutiérrez et al., 2016; Scharroba et al., 2016; Zhao et al., 2016; Čerevková et al., 2017). Liang et al. (2009) reported that total nematode abundance responded positively to manure treatments in monoculture maize fields. $\mathrm{Hu}$ \& Qi (2013) found that long-term application of micro-organic compost could increase nematode abundance in wheat fields. So far, all studies about the effects of fertilization on the nematode community have mainly focused on the upland cropping systems. However, few investigations have reported the effects of long-term application of inorganic and organic fertilizer on soil nematode communities in the paddy-upland rotation system. Therefore, the aims of this study are to (1) determine the impacts of long-term fertilization on the soil nematode community, (2) compare the differences of the nematode communities under organic manure and inorganic fertilizer treatments in the paddy rice-upland wheat rotation systems.

\section{Materials and Methods}

\section{Study site}

An ongoing long-term (thirty-three years) fertilizer experiment in a rice-wheat rotation system was initiated from rice cultivation in 1981, belonging to the National Fertilizer Experiment Monitoring Network at Nanhu Experimental Station, Hubei Academy of Agricultural Sciences in Wuchang China, located at latitude $30^{\circ} 28^{\prime} \mathrm{N}$, longitude $114^{\circ} 25^{\prime} \mathrm{E}$ and at an altitude of 20 meters in central China. The experimental site lies in a subtropical monsoon zone, which

Table 1. Soil properties $(0-20 \mathrm{~cm})$ in different fertilization treatments in October 2012.

\begin{tabular}{lcccccc}
\hline Treatment & $\begin{array}{c}\text { Organic Matter } \\
\left(\mathbf{g ~ k g}^{-1}\right)\end{array}$ & $\begin{array}{c}\text { Total N } \\
\left(\mathbf{g ~ k g}^{-1}\right)\end{array}$ & $\begin{array}{c}\text { Alkaline N } \\
\left(\mathbf{m g ~ k g}^{-1}\right)\end{array}$ & $\begin{array}{c}\text { Available P } \\
\left(\mathbf{m g ~ k g}^{-1}\right)\end{array}$ & $\begin{array}{c}\text { Available K } \\
\left(\mathbf{m g ~ k g}^{-1}\right)\end{array}$ & $\mathbf{p H}$ \\
\hline Control & $21.69 \mathrm{c}$ & $1.64 \mathrm{c}$ & $112.22 \mathrm{~b}$ & $8.21 \mathrm{c}$ & $105.63 \mathrm{bc}$ & $7.17 \mathrm{ab}$ \\
$\mathrm{N}$ & $22.02 \mathrm{c}$ & $1.79 \mathrm{bc}$ & $113.88 \mathrm{~b}$ & $8.71 \mathrm{c}$ & $94.77 \mathrm{bc}$ & $7.37 \mathrm{ab}$ \\
$\mathrm{NP}$ & $26.02 \mathrm{~b}$ & $1.86 \mathrm{bc}$ & $129.51 \mathrm{~b}$ & $18.71 \mathrm{c}$ & $93.12 \mathrm{c}$ & $7.57 \mathrm{a}$ \\
$\mathrm{NPK}$ & $26.54 \mathrm{~b}$ & $1.88 \mathrm{~b}$ & $134.35 \mathrm{~b}$ & $18.33 \mathrm{c}$ & $117.66 \mathrm{bc}$ & $7.22 \mathrm{ab}$ \\
$\mathrm{MN}$ & $36.74 \mathrm{a}$ & $2.71 \mathrm{a}$ & $188.98 \mathrm{a}$ & $130.69 \mathrm{~b}$ & $139.14 \mathrm{bc}$ & $7.22 \mathrm{ab}$ \\
$\mathrm{MNP}$ & $34.72 \mathrm{a}$ & $2.61 \mathrm{a}$ & $173.51 \mathrm{a}$ & $136.73 \mathrm{~b}$ & $141.27 \mathrm{~b}$ & $7.30 \mathrm{ab}$ \\
MNPK & $34.04 \mathrm{a}$ & $2.70 \mathrm{a}$ & $189.01 \mathrm{a}$ & $151.32 \mathrm{a}$ & $205.94 \mathrm{a}$ & $7.03 \mathrm{~b}$ \\
\hline
\end{tabular}

Control, the unfertilized treatment; $\mathrm{N}$, the inorganic nitrogen fertilizer treatment; NP, the inorganic nitrogen and phosphorus fertilizer treatment; NPK, the inorganic nitrogen, phosphorus and potassium fertilizer treatment; $\mathrm{MN}$, the manure plus inorganic nitrogen fertilizer treatment; MNP, the manure plus inorganic nitrogen and phosphorus fertilizer treatment; MNPK, the manure plus inorganic nitrogen, phosphorus and potassium fertilizer treatment.

Different letters $(a, b, c)$ in the same column indicate significant differences $(P<0.05)$ among treatments according to LSD multiple comparison. 
is characterized by hot summers and severe winters, and occasional snowfall during winter. The mean annual temperature is 13 ${ }^{\circ} \mathrm{C}$, ranging from a minimum of $3.7^{\circ} \mathrm{C}$ in January to a maximum of $28.8^{\circ} \mathrm{C}$ in July. The mean annual precipitation is $1300 \mathrm{~mm}$, and the annual non-frost period is 240 days from 1981 to 2013. The soil at the experimental site is yellow-brown soil, belonging to the Albic Luvisol in the FAO classification, which has a clay-loam texture with $15 \%$ sand, $36 \%$ silt, and $49 \%$ clay. Soil physicalchemical properties in October 2012 at an $0-20 \mathrm{~cm}$ depth were shown in Table 1.

\section{Experimental design}

The field experiment was constituted of seven treatments and three replicates in a randomized complete block design. Each plot was $40 \mathrm{~m}^{2}$ ( $5 \mathrm{~m}$ width $\times 8 \mathrm{~m}$ length). The seven treatments were as follows: (1) the unfertilized treatment, control; (2) the inorganic $\mathrm{N}$ fertilizer treatment, $\mathrm{N}$; (3) the inorganic $\mathrm{N}$ and $\mathrm{P}$ fertilizer treatment, NP; (4) the inorganic N, P and K fertilizer treatment, NPK; (5) the manure plus inorganic $\mathrm{N}$ fertilizer treatment, $\mathrm{MN}$; $(6)$ the manure plus inorganic $\mathrm{N}$ and $\mathrm{P}$ fertilizer treatment, MNP; and (7) the manure plus inorganic $\mathrm{N}, \mathrm{P}$ and $\mathrm{K}$ fertilizer treatment, MNPK. The chemical fertilizers were applied at an annual rate of $150 \mathrm{~kg} \mathrm{~N} \mathrm{ha}^{-1}$, $75 \mathrm{~kg} \mathrm{P}_{2} \mathrm{O}_{5}$ ha-1 $^{-1}$, and $150 \mathrm{~kg} \mathrm{~K}_{2} \mathrm{O}$ ha $^{-1}$ (Zhang et al., 2017b). The $\mathrm{N}$,
$\mathrm{P}$, and $\mathrm{K}$ fertilizers were applied as urea, ammonium phosphate, and potassium chloride, respectively. $22,500 \mathrm{~kg} \mathrm{ha}^{-1}$ of organic fertilizers from pig dung compost was applied to the MN, MNP and MNPK treatments. The pig dung compost contained an average of $282.05 \mathrm{~g} \mathrm{~kg}^{-1}$ organic $\mathrm{C}, 15.08 \mathrm{~g} \mathrm{~kg}^{-1}$ total $\mathrm{N}, 20.84 \mathrm{~g} \mathrm{~kg}^{-1} \mathrm{P}_{2} \mathrm{O}_{5}$, $13.56 \mathrm{~g} \mathrm{~kg}^{-1} \mathrm{~K}_{2} \mathrm{O}$, and $69 \%$ water. $60 \%$ of inorganic fertilizers were applied during the rice growth season and the other $40 \%$ during the wheat growth season, while manure was applied equally (50:50) to the two crops. The $\mathrm{N}$ fertilizer was applied three times in the rice growth season. Namely, $40 \%$ of the $\mathrm{N}$ fertilizer as basal fertilizer was applied before the cultivating rice, $40 \%$ was applied during the rice tillering stage and $20 \%$ was applied during the rice booting stage. Similarly, the $\mathrm{N}$ fertilizer was also applied three times in the wheat growth season. Namely, $50 \%$ of $\mathrm{N}$ fertilizer as basal fertilizer was applied before the planting wheat, $25 \%$ during the wheat seedling stage and $25 \%$ was applied during the jointing stage in the wheat growth season. Every year, the $P, K$ fertilizers and manure were applied as basal fertilizer, prior to plough. All basal fertilizers and manure were evenly sprinkled on the soil surface by hand and were incorporated into the plough layer by tillage as soon as possible. Tillage was performed to a depth of $20 \mathrm{~cm}$ by a plough, followed by a harrow. The fertilized and unfertilized plots were tilled similarly.

Table 2. The number of soil nematodes (individuals $100 \mathrm{~g}^{-1} \mathrm{dry}$ soil) after different fertilization treatments in rice and wheat fields.

\begin{tabular}{|c|c|c|c|c|c|c|c|}
\hline & Treatment & FN & $\mathrm{BF}$ & $\mathrm{FF}$ & $\mathrm{PF}$ & OP & Prodorylaimus \\
\hline Rice & Control & $262.8 d$ & $71.9 a$ & $6.9 a$ & $110.7 a$ & $184.1 \mathrm{~d}$ & $82.3 d$ \\
\hline \multirow[t]{6}{*}{ field } & $\mathrm{N}$ & $270.2 d$ & $75.2 a$ & $8.4 a$ & $195.2 a$ & $186.6 \mathrm{~d}$ & $93.6 \mathrm{~d}$ \\
\hline & $\mathrm{NP}$ & $339.0 \mathrm{~d}$ & $104.9 \mathrm{a}$ & $11.6 a$ & $181.4 a$ & $222.5 \mathrm{~d}$ & $128.7 \mathrm{~cd}$ \\
\hline & NPK & $477.2 \mathrm{c}$ & $141.2 \mathrm{a}$ & $6.0 a$ & $173.7 a$ & $330.0 \mathrm{c}$ & $197.6 \mathrm{c}$ \\
\hline & $\mathrm{MN}$ & $619.1 \mathrm{~b}$ & $113.2 \mathrm{a}$ & $7.2 \mathrm{a}$ & $151.7 a$ & $498.7 \mathrm{~b}$ & $446.8 b$ \\
\hline & MNP & 704.1ab & $66.0 \mathrm{a}$ & $5.2 \mathrm{a}$ & $117.0 \mathrm{a}$ & $633.0 \mathrm{a}$ & $561.0 \mathrm{a}$ \\
\hline & MNPK & $772.2 \mathrm{a}$ & $129.5 a$ & $5.9 a$ & $111.7 a$ & $636.7 \mathrm{a}$ & $588.7 a$ \\
\hline Wheat & Control & $470.2 c$ & $65.9 b c$ & $10.0 \mathrm{a}$ & $210.8 a$ & $394.3 \mathrm{c}$ & $178.6 \mathrm{~d}$ \\
\hline \multirow[t]{6}{*}{ field } & $\mathrm{N}$ & $562.2 \mathrm{c}$ & $89.0 b c$ & $2.5 a$ & $173.9 \mathrm{a}$ & $470.7 c$ & $170.0 \mathrm{~d}$ \\
\hline & NP & $578.6 \mathrm{c}$ & 134.0ab & $0.0 \mathrm{a}$ & $213.0 \mathrm{a}$ & $444.7 \mathrm{c}$ & $176.5 \mathrm{~d}$ \\
\hline & NPK & $942.8 b c$ & $195.2 \mathrm{a}$ & $11.2 \mathrm{a}$ & $202.2 a$ & $736.3 b c$ & $499.7 \mathrm{~cd}$ \\
\hline & $\mathrm{MN}$ & $1238.2 b$ & $162.1 \mathrm{a}$ & $0.0 \mathrm{a}$ & $232.4 a$ & $1076.1 \mathrm{~b}$ & $971.3 b c$ \\
\hline & MNP & $1293.0 \mathrm{~b}$ & $58.8 \mathrm{c}$ & $3.9 a$ & $195.2 a$ & $1230.2 a b$ & 1103.3ab \\
\hline & MNPK & $1907.2 \mathrm{a}$ & 195. $6 a$ & $4.0 \mathrm{a}$ & $115.9 a$ & $1707.6 \mathrm{a}$ & $1591.2 a$ \\
\hline
\end{tabular}

FN: the number of free-living nematodes in soil; BF: bacterial feeders; FF: fungal feeders; PF: plant feeders; OP: omnivores and predators. Control, the unfertilized treatment; N, the inorganic nitrogen fertilizer treatment; NP, the inorganic nitrogen and phosphorus fertilizer treatment; NPK, the inorganic nitrogen, phosphorus and potassium fertilizer treatment; MN, the manure plus inorganic nitrogen fertilizer treatment; MNP, the manure plus inorganic nitrogen and phosphorus fertilizer treatment; MNPK, the manure plus inorganic nitrogen, phosphorus and potassium fertilizer treatment.

Different letters $(a, b, c)$ in the same column indicate significant differences $(P<0.05)$ among treatments at the same sampling times according to LSD multiple comparison. 
All plots were transplanted with rice seedlings (Oryza sativa L.) in summer and were sown with wheat seeds (Triticum aestivum L.) in winter, which has been done annually since 1981. The rice was transplanted in June and harvested in October, and the wheat was directly sown in November and harvested in May of the next year. The above-ground crops were harvested with a sickle and removed; thus, no straw returned into the soil in any plot. Nevertheless, rice or wheat stubble and roots were incorporated into the soil with a plow before the subsequent rice or wheat planting. In addition to the fertilizer treatments, all other agronomic managements were identical in the fertilized and unfertilized plots.

Rice and wheat grains were separated from straws using a plot thresher. Grains and straw were weighed after sun-drying and recorded from the whole plot.

\section{Soil sampling}

Soil samples from the upper $(0-20 \mathrm{~cm})$ soil layer were collected in the rice and wheat maturity stages in October 2012 and in May 2013 , respectively. Composite soil samples consisting of ten cores (2.5 cm diameter $\times 20 \mathrm{~cm}$ depth) were collected from each plot. Soil samples were stored in tied and insulated plastic bags to prevent moisture loss. They were transferred to $4{ }^{\circ} \mathrm{C}$ storage as soon as possible until they were used to analyze the soil nematode community structure.

A

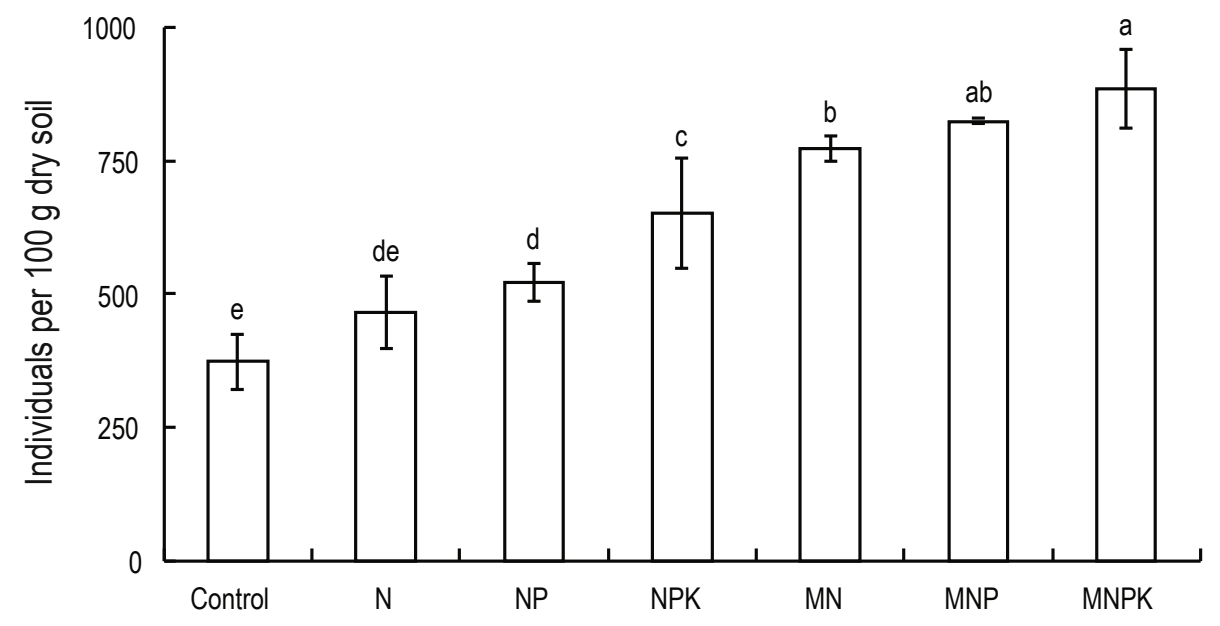

Treatments

B

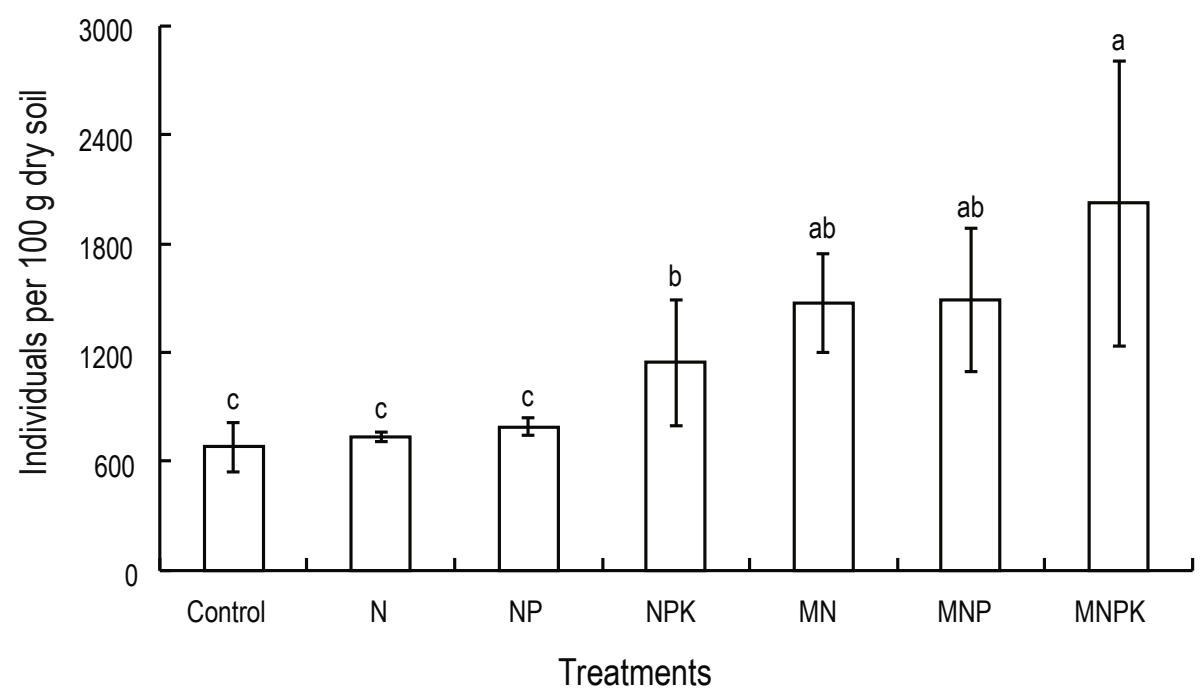

Fig. 1. Total nematode abundance after different fertilization treatments in the rice field (A) and wheat field (B). Control, the unfertilized treatment; $N$, the inorganic nitrogen fertilizer treatment; NP, the inorganic nitrogen and phosphorus fertilizer treatment; NPK, the inorganic nitrogen, phosphorus and potassium fertilizer treatment; MN, the manure plus inorganic nitrogen fertilizer treatment; MNP, the manure plus inorganic nitrogen and phosphorus fertilizer treatment; MNPK, the manure plus inorganic nitrogen, phosphorus and potassium fertilizer treatment. Data are means $\pm \operatorname{SD}(n=3)$. Different letters $(a, b, c)$ above the column indicate significant differences $(P<0.05)$ among treatments according to LSD multiple comparison. 


\section{Soil physical-chemical properties analysis}

Soil samples collected from the $0-20 \mathrm{~cm}$ were air-dried at room temperature, mixed, sieved through a $1-\mathrm{mm}$ screen, and sub-samples were used to analyze soil physical-chemical properties. The air-dried sub-samples were ground to pass through a $0.25-\mathrm{mm}$ sieve to determine soil organic matter and total $\mathrm{N}$ contents. The potassium dichromate external heating method was used to determine soil organic matter content (Blakemore et al., 1972). The Kjeldahl method and the alkaline-hydrolysable diffusion method were used to determine total $\mathrm{N}$ and alkaline-hydrolysable $\mathrm{N}$ content (Bremner, 1996). Soil available $P$ was extracted with $0.5 \mathrm{~mol}$ $\mathrm{L}^{-1} \mathrm{NaHCO}_{3}$ (soil: solution=1:20) and measured with the Olsen method (Olsen et al., 1954). Soil available K was extracted with 1 mol L-1 $\mathrm{NH}_{4} \mathrm{Ac}$ (soil: solution=1:10) and measured with the flame photometry method (Carson, 1980). Soil pH was measured with $0.01 \mathrm{~mol} \mathrm{~L}^{-1} \mathrm{CaCl}_{2}$ slurry (soil: solution=1:2.5) using a glass electrode (Lu, 1999).

\section{Nematode analysis}

Field moist subsamples $(100 \mathrm{~g})$ of each sample were used to extract nematodes with the sugar flotation and centrifugation method (Barker et al., 1985). The nematode populations were expressed as $100 \mathrm{~g} \mathrm{~g}^{-1}$ dry soil. After counting the total number of nematodes using an anatomical lens, two hundred nematodes per sample were randomly selected and identified to genus according to esophageal and morphology characteristics using an inverted compound microscope (Mal \& Lyon, 1975; Ying, 1998).

The characteristics of the nematode communities were described using the following approaches: (1) total number of nematodes per $100 \mathrm{~g}$ dry soil; (2) the number of soil free-living nematodes per $100 \mathrm{~g}$ dry soil; (3) trophic groups: (a) bacterial feeders; (b) fungal feeders; (c) plant feeders; and (d) omnivore-predators (Yeates et al. 1993).

\section{Statistical analysis}

One-way variance analysis (one-way ANOVA) was used to detect differences between different treatments. Differences at the $P<0.05$ level were considered statistically significant under the least significant difference (LSD) test. All statistical analyses and the stepwise regression were performed using SPSS 18.0 version software package.

\section{Ethical Approval and/or Informed Consent}

This article does not contain any studies with human participants or animals by any of the authors.

\section{Results}

\section{Soil physical-chemical properties}

Soil organic matter, total $\mathrm{N}$, alkaline-hydrolysable $\mathrm{N}$ and available $P$ content were significantly $(F=82.892, P<0.001$ in soil organic matter; $F=39.068, P<0.001$ in soil total $\mathrm{N} ; F=18.383, P<0.001$ in alkaline-hydrolysable $\mathrm{N} ; F=224.353, P<0.001$ in available $P$ ) higher in the manure combined with chemical fertilizer treatment than in the chemical fertilizer alone and unfertilized treatment. Soil available $\mathrm{K}$ content were significantly $(F=6.443, P=0.002)$ higher in the manure combined with NPK fertilizer treatment than in the other fertilization treatments and unfertilized control (Table 1).

Total nematode abundance

Total number of nematodes had an increasing tendency with soil nutrient input increments in rice and wheat fields (Fig. 1). Total number of nematode was $1.25-2.37$ times greater in rice field and was $1.08-2.97$ times greater in wheat field in the fertilization treatments than in the unfertilized treatment. In particular, the increase was significant in the NPK and manure combined with the chemical fertilizer treatments $(F=31.452, P<0.001$ in rice field; $F$ $=5.253, P=0.005$ in wheat field).

Nematode trophic group abundance

Like the total number of nematodes, the number of soil free-living nematodes (bacterial-feeders + fungal-feeders + omnivores + predators) had an increasing tendency with soil nutrient input increments in rice and wheat fields. In particular, the increase was significant $(F=41.455, P<0.001)$ in the manure combined with chemical fertilizer treatments in rice field. Moreover, the number of soil free-living nematodes were significantly $(F=9.890, P=0.005)$ higher in the NPK treatment than in the NP, N and unfertilized treatments under the rice field (Table 2).

The bacteria-feeding nematode abundance was not significantly different among treatments in rice field; however, the bacteria-feeding nematode abundances were significantly ( $F=$ $6.000, P=0.003$ ) higher in the MNPK, MN, NPK treatments than in the MNP, N and unfertilized treatments in wheat field (Table 2). The fungi-feeding nematode were the least abundant trophic group in this study. Plant-feeding nematodes were the second-most dominant trophic groups. The number of fungi-feeding and plant-feeding nematodes were not significantly different among treatments in rice and wheat fields. The omnivorous and predatory nematodes were the most dominant groups in the present study (Table 2). The number of omnivore-predators was $1.01-3.46$ times greater in rice field and was $1.19-4.33$ times greater in wheat field in the fertilization treatments than in the unfertilized treatment. In particular, omnivore and predator abundances were significantly ( $F=58.636, P<0.001$ ) higher in the manure combined with the chemical fertilizer treatments than in the chemical fertilizer alone and the unfertilized treatments in rice field. Omnivore and predator abundances were significantly $(F=5.553, P=0.013)$ higher in the MNPK treatment than in the chemical fertilizer alone and unfertilized treatments in wheat field. Omnivore and predator abundances were significantly $(F=9.640, P=0.005)$ higher in the NPK treatment than in the NP, N and unfertilized treatments in rice field. A total of 39 nematode taxa were identified in the present study, of which 11 were bacterial feeders, 5 were fungal feeders, 6 were plant feeders, 12 were omnivores and 5 were predators 
Table 3. The number of soil nematode taxa (individuals $100 \mathrm{~g}^{-1}$ dry soil) for each treatment in rice field.

\begin{tabular}{|c|c|c|c|c|c|c|c|c|}
\hline Genus & Guild & Control & $\mathrm{N}$ & NP & NPK & MN & MNP & MNPK \\
\hline Protorhabditis & $\mathrm{Ba} 1$ & 0.0 & 0.0 & 1.9 & 0.0 & 0.0 & 0.0 & 0.0 \\
\hline Rhabditis & $\mathrm{Ba} 1$ & 0.0 & 0.0 & 0.0 & 0.0 & 0.0 & 0.0 & 3.1 \\
\hline Panagrolaimus & Ba1 & 1.3 & 3.3 & 3.7 & 4.0 & 7.3 & 2.6 & 42.4 \\
\hline Cephalobus & $\mathrm{Ba} 2$ & 4.2 & 6.6 & 1.9 & 0.0 & 0.0 & 2.6 & 0.0 \\
\hline Eucephalobus & Ba2 & 3.7 & 1.7 & 3.4 & 4.8 & 4.8 & 2.6 & 6.3 \\
\hline Acrobeloides & $\mathrm{Ba} 2$ & 3.3 & 3.8 & 0.0 & 0.0 & 9.6 & 0.0 & 3.1 \\
\hline Monhystera & $\mathrm{Ba} 2$ & 0.0 & 0.0 & 0.0 & 1.9 & 2.4 & 0.0 & 0.0 \\
\hline Plectus & $\mathrm{Ba} 2$ & 3.8 & 6.7 & 8.7 & 17.5 & 24.8 & 26.6 & 13.7 \\
\hline Prismatolaimus & $\mathrm{Ba} 3$ & 4.6 & 4.6 & 10.0 & 30.6 & 14.7 & 10.6 & 30.8 \\
\hline Pseudoaulolaimus & $\mathrm{Ba} 3$ & 48.9 & 44.2 & 73.5 & 80.3 & 39.8 & 18.2 & 24.7 \\
\hline Amphidelus & Ba4 & 2.0 & 4.2 & 1.9 & 2.0 & 9.8 & 2.7 & 5.2 \\
\hline Aphelenchoides & Fu2 & 0.0 & 0.0 & 1.9 & 0.0 & 7.2 & 5.2 & 5.9 \\
\hline Tylencholaimus & Fu4 & 2.5 & 0.0 & 1.9 & 0.0 & 0.0 & 0.0 & 0.0 \\
\hline Doryllium & Fu4 & 3.1 & 8.4 & 7.8 & 6.0 & 0.0 & 0.0 & 0.0 \\
\hline Leptonchus & Fu4 & 1.3 & 0.0 & 0.0 & 0.0 & 0.0 & 0.0 & 0.0 \\
\hline Malenchus & $\mathrm{H} 2$ & 20.8 & 14.9 & 20.1 & 4.3 & 12.5 & 5.4 & 0.0 \\
\hline Basiria & $\mathrm{H} 2$ & 43.5 & 126.4 & 96.5 & 98.9 & 35.3 & 48.0 & 39.2 \\
\hline Psilenchus & $\mathrm{H} 2$ & 22.9 & 22.5 & 22.3 & 4.8 & 4.8 & 0.0 & 0.0 \\
\hline Tylenchorhynchus & $\mathrm{H} 3$ & 0.0 & 0.0 & 0.0 & 0.0 & 32.5 & 13.4 & 11.1 \\
\hline Hirschmanniella & $\mathrm{H} 3$ & 22.1 & 24.8 & 33.3 & 56.0 & 66.6 & 50.2 & 61.4 \\
\hline Belondira & H5 & 1.4 & 6.6 & 9.3 & 9.7 & 0.0 & 0.0 & 0.0 \\
\hline Pristionchus & Om1 & 0.0 & 0.0 & 0.0 & 0.0 & 4.8 & 2.6 & 5.6 \\
\hline Lordellonema & Om4 & 0.0 & 0.0 & 0.0 & 0.0 & 0.0 & 5.4 & 0.0 \\
\hline Prodorylaimus & Om4 & 82.3 & 93.6 & 128.7 & 197.6 & 446.8 & 561.0 & 588.7 \\
\hline Mesodorylaimus & Om4 & 26.5 & 18.4 & 21.1 & 45.6 & 2.4 & 5.3 & 6.3 \\
\hline Eudorylaimus & Om4 & 13.9 & 12.1 & 0.0 & 14.2 & 15.0 & 15.9 & 3.1 \\
\hline Thorneella & Om4 & 1.4 & 0.0 & 0.0 & 0.0 & 0.0 & 0.0 & 0.0 \\
\hline Pungentus & Om4 & 2.5 & 1.3 & 0.0 & 0.0 & 0.0 & 2.7 & 0.0 \\
\hline Aporcelaimus & Om5 & 7.1 & 4.7 & 3.4 & 2.0 & 22.4 & 13.5 & 5.4 \\
\hline Sectonema & Om5 & 1.3 & 0.0 & 0.0 & 2.4 & 0.0 & 0.0 & 0.0 \\
\hline Tripyla & $\mathrm{Ca} 3$ & 0.0 & 0.0 & 0.0 & 2.4 & 0.0 & 0.0 & 0.0 \\
\hline lotonchus & $\mathrm{Ca} 4$ & 0.0 & 0.0 & 0.0 & 0.0 & 0.0 & 2.7 & 5.4 \\
\hline Mylonchulus & $\mathrm{Ca} 4$ & 0.0 & 1.3 & 3.1 & 2.0 & 2.6 & 8.0 & 10.9 \\
\hline Laevides & $\mathrm{Ca} 5$ & 49.1 & 55.2 & 66.1 & 63.7 & 4.8 & 15.9 & 11.3 \\
\hline
\end{tabular}

Functional guild classifications are made based on the feeding habits and life-cycle characteristics (Ba: bacterivores, Fu: fungivores, Ca: Carnivores, Om: omnivores, H: herbivores) (Yeates, 1993). Suffix numbers are c-p values for the taxon (Bongers \& Bongers, 1998). Control, the unfertilized treatment; $\mathrm{N}$, the inorganic nitrogen fertilizer treatment; NP, the inorganic nitrogen and phosphorus fertilizer treatment; NPK, the inorganic nitrogen, phosphorus and potassium fertilizer treatment; MN, the manure plus inorganic nitrogen fertilizer treatment; MNP, the manure plus inorganic nitrogen and phosphorus fertilizer treatment; MNPK, the manure plus inorganic nitrogen, phosphorus and potassium fertilizer treatment. 
Table 4. The number of soil nematode taxa (individuals $100 \mathrm{~g}^{-1}$ dry soil) for each treatment in wheat field.

\begin{tabular}{|c|c|c|c|c|c|c|c|c|}
\hline Genus & Guild & Control & $\mathbf{N}$ & NP & NPK & MN & MNP & MNPK \\
\hline Protorhabditis & $\mathrm{Ba1}$ & 0.0 & 4.8 & 0.0 & 0.0 & 0.0 & 0.0 & 0.0 \\
\hline Rhabditis & $\mathrm{Ba1}$ & 0.0 & 0.0 & 2.6 & 0.0 & 0.0 & 0.0 & 0.0 \\
\hline Panagrolaimus & $\mathrm{Ba} 1$ & 0.0 & 11.8 & 10.5 & 7.8 & 23.3 & 4.0 & 4.0 \\
\hline Cephalobus & $\mathrm{Ba} 2$ & 2.7 & 2.3 & 2.7 & 6.2 & 4.0 & 0.0 & 0.0 \\
\hline Eucephalobus & $\mathrm{Ba} 2$ & 0.0 & 0.0 & 0.0 & 0.0 & 4.0 & 4.0 & 0.0 \\
\hline Acrobeloides & $\mathrm{Ba} 2$ & 0.0 & 4.8 & 2.6 & 0.0 & 4.0 & 0.0 & 0.0 \\
\hline Monhystera & Ba2 & 4.7 & 0.0 & 2.5 & 3.2 & 0.0 & 0.0 & 13.9 \\
\hline Plectus & Ba2 & 0.0 & 14.7 & 28.3 & 69.8 & 30.7 & 22.2 & 93.9 \\
\hline Prismatolaimus & Ba3 & 9.7 & 21.1 & 56.5 & 32.6 & 47.3 & 15.7 & 54.9 \\
\hline Pseudoaulolaimus & Ba3 & 48.9 & 29.4 & 28.3 & 72.5 & 49.1 & 13.0 & 28.8 \\
\hline Amphidelus & $\mathrm{Ba} 4$ & 0.0 & 0.0 & 0.0 & 3.2 & 0.0 & 0.0 & 0.0 \\
\hline Aphelenchoides & Fu2 & 2.3 & 0.0 & 0.0 & 0.0 & 0.0 & 0.0 & 0.0 \\
\hline Ditylenchus & Fu2 & 0.0 & 0.0 & 0.0 & 0.0 & 0.0 & 3.9 & 0.0 \\
\hline Tylencholaimus & Fu4 & 0.0 & 0.0 & 0.0 & 4.8 & 0.0 & 0.0 & 0.0 \\
\hline Doryllium & Fu4 & 7.7 & 2.5 & 0.0 & 6.4 & 0.0 & 0.0 & 4.0 \\
\hline Malenchus & $\mathrm{H} 2$ & 0.0 & 2.3 & 5.1 & 14.7 & 0.0 & 0.0 & 0.0 \\
\hline Basiria & $\mathrm{H} 2$ & 136.4 & 115.7 & 105.2 & 75.4 & 106.1 & 76.6 & 36.9 \\
\hline Psilenchus & $\mathrm{H} 2$ & 5.2 & 7.3 & 23.0 & 12.6 & 5.7 & 0.0 & 0.0 \\
\hline Tylenchorhynchus & $\mathrm{H} 3$ & 2.7 & 0.0 & 0.0 & 0.0 & 34.2 & 58.3 & 18.1 \\
\hline Hirschmanniella & $\mathrm{H} 3$ & 66.5 & 43.8 & 77.0 & 88.8 & 86.4 & 60.3 & 60.9 \\
\hline Belondira & $\mathrm{H} 5$ & 0.0 & 4.9 & 2.7 & 10.7 & 0.0 & 0.0 & 0.0 \\
\hline Pristionchus & Om1 & 6.4 & 16.9 & 12.8 & 3.2 & 7.9 & 11.8 & 13.9 \\
\hline Coomansinema & Om4 & 0.0 & 0.0 & 2.7 & 0.0 & 4.0 & 4.0 & 0.0 \\
\hline Ecumenicus & Om4 & 2.3 & 0.0 & 0.0 & 0.0 & 0.0 & 0.0 & 0.0 \\
\hline Prodorylaimus & Om4 & 178.6 & 170.0 & 176.5 & 499.7 & 971.3 & 1103.3 & 1591.2 \\
\hline Mesodorylaimus & Om4 & 57.8 & 79.7 & 65.0 & 63.4 & 13.6 & 23.4 & 18.1 \\
\hline Eudorylaimus & Om4 & 6.4 & 0.0 & 2.5 & 0.0 & 0.0 & 7.9 & 26.7 \\
\hline Thorneella & Om4 & 7.3 & 0.0 & 0.0 & 0.0 & 0.0 & 0.0 & 0.0 \\
\hline Pungentus & Om4 & 13.5 & 12.3 & 15.3 & 6.4 & 0.0 & 7.9 & 0.0 \\
\hline Aporcelaimus & Om5 & 10.5 & 7.4 & 2.7 & 34.5 & 24.1 & 18.3 & 33.9 \\
\hline Labronema & Om4 & 0.0 & 7.3 & 0.0 & 0.0 & 0.0 & 7.9 & 0.0 \\
\hline Sectonema & Om5 & 5.0 & 4.8 & 5.1 & 0.0 & 0.0 & 0.0 & 0.0 \\
\hline Tripyla & Ca3 & 2.3 & 0.0 & 10.5 & 9.6 & 8.8 & 3.9 & 5.9 \\
\hline Miconchus & $\mathrm{Ca} 4$ & 8.0 & 9.7 & 12.6 & 24.1 & 9.7 & 16.9 & 4.0 \\
\hline Iotonchus & Ca4 & 2.3 & 9.7 & 0.0 & 0.0 & 9.6 & 10.4 & 0.0 \\
\hline Laevides & Ca5 & 93.7 & 152.9 & 139.1 & 95.5 & 27.2 & 14.3 & 13.9 \\
\hline
\end{tabular}

Functional guild classifications are made based on the feeding habits and life-cycle characteristics (Ba: bacterivores, Fu: fungivores, Ca: carnivores (predators), Om: omnivores, $\mathrm{H}$, plant feeders (herbivores) (Yeates, 1993). Suffix numbers are c-p values for the taxon (Bongers \& Bongers, 1998). Control, the unfertilized treatment; N, the inorganic nitrogen fertilizer treatment; NP, the inorganic nitrogen and phosphorus fertilizer treatment; NPK, the inorganic nitrogen, phosphorus and potassium fertilizer treatment; MN, the manure plus inorganic nitrogen fertilizer treatment; MNP, the manure plus inorganic nitrogen and phosphorus fertilizer treatment; MNPK, the manure plus inorganic nitrogen, phosphorus and potassium fertilizer treatment. 
Table 5. Crop grain yields after different fertilization treatments.

\begin{tabular}{lcc}
\hline Treatment & Rice grain yield (t/ha) & Wheat grain yield (t/ha) \\
\hline Control & $3.79 \mathrm{~d}$ & $2.24 \mathrm{c}$ \\
$\mathrm{N}$ & $4.66 \mathrm{~cd}$ & $2.32 \mathrm{c}$ \\
$\mathrm{NP}$ & $5.13 \mathrm{bc}$ & $3.13 \mathrm{~b}$ \\
$\mathrm{NPK}$ & $5.17 \mathrm{bc}$ & $3.23 \mathrm{~b}$ \\
$\mathrm{MN}$ & $6.04 \mathrm{ab}$ & $4.56 \mathrm{a}$ \\
MNP & $6.10 \mathrm{ab}$ & $4.65 \mathrm{a}$ \\
MNPK & $6.55 \mathrm{a}$ & $4.74 \mathrm{a}$ \\
\hline
\end{tabular}

Control, the unfertilized treatment; N, the inorganic nitrogen fertilizer treatment; NP, the inorganic nitrogen and phosphorus fertilizer treatment; NPK, the inorganic nitrogen, phosphorus and potassium fertilizer treatment; MN, the manure plus inorganic nitrogen fertilizer treatment; MNP, the manure plus inorganic nitrogen and phosphorus fertilizer treatment; MNPK, the manure plus inorganic nitrogen, phosphorus and potassium fertilizer treatment.

Different letters $(a, b, c)$ in the same column indicate significant differences $(P<0.05)$ among treatments according to LSD multiple comparison.

(Table 3, 4). The number of Prodorylamus were significantly $(F=$ 46.0201, $P<0.05)$ higher in the manure combined with the chemical fertilizer treatment than in the chemical fertilizer alone and the unfertilized treatments in rice field (Table 2).

\section{Crop yield}

Rice and wheat yields were significantly $(F=3.764, P=0.019$ in rice; $F=91.648, P<0.001$ in wheat) influenced by the different fertilization treatments (Table 5). Rice grain yields were 1.23-1.73 times greater in the fertilization treatments than in the unfertilized treatment. In particular, rice grain yields were significantly $(F=$ $5.265, P=0.015)$ higher in the MNPK treatment than in the chemical fertilizer alone and the unfertilized treatments. Rice grain yields were significantly $(F=5.415, P=0.014)$ higher in the MNPK, MNP, $\mathrm{MN}$ treatments than in the $\mathrm{N}$ and unfertilized treatments; nevertheless, there were no significant differences between the $\mathrm{N}$ and unfertilized treatments.

Wheat grain yields were $1.04-2.12$ times greater in the fertilization treatments than in the unfertilized treatment. Wheat grain yields were significantly $(F=91.648, P<0.001)$ higher in the manure combined with the chemical fertilizer treatments than in the chemical fertilizer alone and in the unfertilized treatments. Moreover, wheat grain were significantly $(F=19.641, P<0.001)$ higher in the NPK, NP treatments than in the $\mathrm{N}$ alone and in the unfertilized treatments; nevertheless, there was no significant difference between the $\mathrm{N}$ alone and the unfertilized treatments.

\section{Regression analysis}

Stepwise regression equations were conducted to evaluate soil nematode community parameters in rice and wheat fields. These parameters were significantly associated with rice and wheat grain yields. The number of soil free-living nematode was found to be a significant $(F=23.968, P<0.001)$ predictor of rice grain yields. The number of omnivorous and predatory nematodes was found to be a significant $(F=150.214, P<0.001)$ predictor of wheat grain yields (Table 6).

\section{Discussion}

Compared to the unfertilized treatment, the total number of nematode was increased in rice and wheat fields due to fertilizer application. In particular, there was a significant increase in the NPK and manure combined with the chemical fertilizer treatments. Similarly, increasing total nematode abundances after application of manure were also reported by Villenave et al. (2003), Forge et al. (2005) and Hu \& Qi (2013). The increase of nematode populations could possibly be linked directly to higher food resources associated with the input of organic matter (Villenave et al., 2003). Increasing total number of nematodes due to application of chemical fertilizer was also reported by other studies (Li et al., 2016; Hu et al., 2017). Villenave et al. (2010) also observed that soil free-living nematodes were increased due to organic and mineral fertilizer use.

Table 6. Stepwise regression of grain yields of rice and wheat with the soil nematode community.

\begin{tabular}{lcccccc}
\hline & Predictor variable & Constant & Coefficient & $\boldsymbol{R}^{2}$ & $\boldsymbol{F}$ & $\boldsymbol{P}$ \\
\hline Rice & FN & 3.368 & 0.004 & 0.558 & 23.968 & $<0.001$ \\
Wheat & OP & 1.613 & 0.005 & 0.888 & 150.214 & $<0.001$ \\
\hline
\end{tabular}

FN: the number of soil free-living nematodes; OP: the number of omnivorous and predatory nematodes.

The values are fitted in the equation: $y=a+b x_{1}+c x_{2} ; y=$ grain yield; $x_{1}$ and $x_{2}$ are the independent variables; and $a, b$ and $c$ are coefficients. 
Fungi-feeding and plant-feeding nematode abundances were not significantly different among treatments in the present study. This result is not consistent with previous studies showing that organic materials application resulted in an increase of fungal feeders abundances (Ferris \& Matute, 2003; Wang et al., 2006; Villenave et al., 2010) and that plant-feeding nematodes were increased due to compost and chemical fertilizer application in a maize field $\mathrm{Hu}$ \& Qi, 2010).

The omnivorous and predatory nematodes were the most dominant groups in the present study. In contrast, bacterial feeders were the most abundant group in paddy field (Ou et al., 2005), in yellow squash field (Wang et al., 2006), and in Horqin sandy land (Jiang et al., 2007; Guan et al., 2015). Plant-feeding nematodes were prevalent in maize and wheat fields (Hu \& Qi, 2010, 2013; Zhang et al., 2012), in sorghum field (Villenave et al., 2010), and in millet field (Diakhaté et al., 2013). Compared to the unfertilized treatment, the abundance omnivore-predators was increased in rice and wheat fields due to fertilizer use. A similar study also showed that the application of manure to an agricultural field could increase the abundance of omnivorous nematodes (Villenave et al., 2004). Li et al. (2010) reported that organic fertilizer application increased the relative abundance of omnivore-carnivores, but different levels of applied nitrogen fertilizer decreased their relative abundance under greenhouse conditions. The composition and abundance of omnivores and carnivores were not affected by the soil amendments (Villenave et al., 2010) and the effect of organic amendment on omnivorous and predatory nematodes was minimal (Wang et al., 2006). However, Forge et al. (2005) reported that high amount manure and chemical fertilizer application reduced omnivorous nematode abundance, but predacious nematodes were more abundant in manure-treated soil than in fertilized soil. Abundant omnivorous and predatory nematodes in the manure-treated soils suggested that more complex soil food webs are expected to result in greater biodiversity of the belowground organisms mediating multiple soil ecosystem functions (Ferris et al., 2012). For example, carnivores, through preying on plant-parasitic nematodes, were regarded as having potential for the biological regulation of pest species (Steel \& Ferris, 2016). The increase of omnivorous and predacious nematodes were beneficial for soil health because omnivores and predators play an important role in further mineralizing soil nutrients tied up in bacteria-feeders or fungi-feeders, as well as preying on other nematodes including plant-parasitic nematodes (Wang et al., 2006; Khan \& Kim, 2007). Prodorylamus were the dominant genera in the present study. However, Helicotylenchus and Scutellonema were predominant in millet field (Diakhaté et al., 2013), Pratylenchus and Tylenchorhynchus were dominant in sorghum field (Villenave et al., 2010) and Tylenchorhynchus, Pratylenchus, and Rotylenchus were the dominant genera in wheat field (Hu \& Qi, 2013). The number of nematode genera (39) in the present study was lower than in paddy field (45) (Lü et al., 2017), in maize field (48) (Liang et al., 2009), and in banana field (56) (Zhong et al., 2017), but similar to the result in a continuous sorghum field (38) (Villenave et al., 2010), in soybean field (37) (Pan et al., 2016), and in Tibetan plateau grassland (41) (Hu et al., 2017).

The number of soil free-living nematode was a significant predictor of rice grain yields and the number of omnivorous and predatory nematode was a significant predictor of wheat grain yields. Similarly, Mandal et al. (2007) reported that alkaline phosphatase activity was significant $(P<0.001)$ for predicting the grain yields of wheat at the dough stages of wheat growth. Hu \& Qi (2013) observed that soil free-living nematode was a significant $(P<0.05)$ predictor of wheat grain yields during the jointing stage of wheat growth.

\section{Conclusions}

Based on these results, we deduced that long-term application of organic manure and chemical fertilizer modified the soil nematode community structure, increased crop yields. Total nematode abundance had an increasing tendency with soil nutrient input increments in rice and wheat fields. The number of total soil nematode was significantly increased due to organic manure combined with the chemical fertilizer application in rice field. Omnivores and predators and Prodorylaimus were significantly higher in the organic manure combined with NPK fertilizer treatments than in the chemical fertilizer alone and in the unfertilized treatments in rice and wheat fields. Stepwise regressions revealed that the number of soil free-living nematode was a significant predictor of rice grain yields $\left(R^{2}=0.56\right)$ and the number of omnivorous and predatory nematode was a significant predictor of wheat grain yield $\left(R^{2}=0.89\right)$. In conclusion, long-term application of organic manure combined with chemical fertilizer could increase nematode abundances and raise crop yields. Organic manure combined with chemical fertilizer application was recommended in agricultural ecosystem.

\section{Conflict of interest}

The authors declare there is no conflict of interest.

\section{Acknowledgements}

This Project Sponsored by the National Key Research and Development Program of China (2018YFD0200500); the Special Fund for Agro-scientific Research in the Public Interest of China (201203030); the Scientific Research Foundation for the Returned Overseas Chinese Scholars, State Education Ministry (2012-940); the Scientific and Technological Key Achievements Cultivation Project of Hubei Academy of Agricultural Sciences (2017CGPY01) and the National Natural Science Foundation of China (31300442).

\section{References}

Barker, K.R., Carter, C.C., Sasser, J.N. (1985): An Advanced 
Treatise on Meloidogyne, Methodology, Vol. 2. North Carolina State University Graphics, Raleigh, NC, pp. 223

Blakemore, L.C., Searle, P.L., Daly, B.K. (1972): Methods for Chemical Analysis of Soils. New Zealand Soil Bureau Report 10 A. Government Printers, Wellington

Bongers, T., Bongers, M. (1998): Functional diversity of nematodes. Appl. Soil Ecol., 10: 253 - 251. DOI: 10.1016/S09291393(98)00123-1

Brar, B.S., Singh, K., Dheri, G.S., Kumar, B. (2013): Carbon sequestration and soil carbon pools in a rice-wheat cropping system: Effect of long-term use of inorganic fertilizers and organic manure. Soil Till. Res., 128: 30 - 36. DOI: 10.1016/j.still.2012.10.001

BRemner, J.M. (1996): Nitrogen-Total. In: Sparks, D.L. (Ed.), Methods of Soil Analysis. Part 3. Soil Science Society of America Book Series 5, Madison, pp. $1085-1086$

CARSON, P.L. (1980): Recommended potassium test. In: Dahnke WC (ed) Recommended chemical soil test procedures for the North Central Region. Bulletin 499. North Dakota Agricultural Experiment Station, Fargo, pp. 17 - 18

Čerevková, A., Miklisová, D., Cagáñ, L. (2017): Effects of experimental insecticide applications and season on soil nematode communities in a maize field. Crop Prot., 92: 1 - 15. DOI: 10.1016/j. cropro.2016.10.007

DebreCZENI, B., KöRschens, M. (2003): Long-term field experiments of the world. Arch. of Agron. Soil Sci., 49(5): 465 - 483. DOI: 10.1080/03650340310001594754

Diacono, M., Montemurro, F. (2010): Long-term effects of organic amendments on soil fertility. A review. Agron. Sustain. Dev., 30(2): 401 - 422. DOI: 10.1051/agro/2009040

Diakhaté, S., Villenave, C., Diallo, N.H., Ba, A.O., Duigal, D., Masse, D., Sembène, P.M., Chapuis-Lardy, L. (2013): The influence of a shrub-based intercropping system on the soil nematofauna when growing millet in Senegal. Eur. J. Soil Biol., 57: 35 - 41. DOI: 10.1016/j.ejsobi.2013.04.003

Ding, J.L., Jiang, X., Guan, D.W., Zhao, B.S., Ma, M.C., Zhou, B.K., CAO, F.M., YANG, X.H., LI, L., LI, J. (2017): Influence of inorganic fertilizer and organic manure application on fungal communities in a long-term field experiment of Chinese Mollisols. Appl. Soil Ecol., 111: 114 - 122. DOI: 10.1016/j.apsoil.2016.12.003

FerRIs, H., Matute, M.M. (2003): Structural and functional succession in the nematode fauna of a soil food web. Appl. Soil Ecol., 23(2): 93 - 110. DOI: 10.1016/S0929-1393(03)00044-1

Ferris, H., Pocasangre, L.E., Serrano, E., Muñoz, J., Garcia, S., Perichi, G., Martinez, G. (2012): Diversity and complexity complement apparent competition: Nematode assemblages in banana plantations. Acta Oecol., 40: 11 - 18. DOI: 10.1016/j.actao.2012.02.003

Forge, T.A., Bittman, S., Kowalenko, C.G. (2005): Responses of grassland soil nematodes and protozoa to multi-year and single-year applications of dairy manure slurry and fertilizer. Soil Biol. Biochem., 37(10): 1751 - 1762. DOI: 10.1016/j.soilbio.2004.11.013 Geisseler, D., Scow, K.M. (2014): Long-term effects of mineral fer- tilizers on soil microorganisms - A review. Soil Biol. Biochem., 75: 54 - 63. DOI: 10.1016/j.soilbio.2014.03.023

Gruzdeva, L.I., Matveeva, E.M., Kovalenko, T.E. (2007): Changes in soil nematode communities under the impact of fertilizers. Eurasian Soil Sci., 40(6): 681 - 693. DOI: 10.1134/S1064229307

Guan, P.T., Zhang, X.K., Yu, J., Ma, N.N., Liang, W.J. (2015): Variation of soil nematode community composition with increasing sand-fixation year of Caragana microphylla: bioindication for desertification restoration. Ecol. Eng., 81: 93 - 101. DOI: 10.1016/j. ecoleng.2015.04.011

Gutiérrez, C., Fernández, C., Escuer, M., Campos-Herrera, R., Rodríguez, M.E.B., Carbonell, G., Martín, J.A.R. (2016): Effect of soil properties, heavy metals and emerging contaminants in the soil nematodes diversity. Environ. Pollut., 213: 184 - 194. DOI: 10.1016/j.envpol.2016.02.012

HoPkINS, D.W., SHIEL, R.S. (1996): Size and activity of soil microbial communities in long-term experimental grassland plots treated with manure and inorganic fertilizers. Biol. Fert. Soils, 22(1-2): 66 - 70. DOI: 10.1007/BF00384434

Hoschitz, M., Kaufmann, R. (2004): Nematode community composition in five alpine habitats. Nematology, 6(5): 737 - 747. DOI: 10.1163/1568541042843531

Hu, C., LI, S.L., QIAO, Y., LIU, D.H., ChEN, Y.F. 2015: Effects of 30 years repeated fertilizer applications on soil properties, microbes and crop yields in rice-wheat cropping systems. Exp. Agr., 51(3): 355 - 369. DOI: $10.1017 /$ S0014479714000350

Hu, C., QI, Y.C. (2010): Effect of compost and chemical fertilizer on soil nematode community in a Chinese maize field. Eur. J. Soil Biol., 46(3 - 4): 230 - 236. DOI: 10.1016/j.ejsobi.2010.04.002

Hu, C., Qı, Y.C. (2013): Effective microorganisms and compost favor nematodes in wheat crops. Agron. Sustain. Dev., 33(3): 573 - 579. DOI: 10.1007/s13593-012-0130-9

Hu, J., Chen, G.R., Hassan, W.M., Chen, H., LI, J.Y., Du, G.Z. (2017): Fertilization influences the nematode community through changing the plant community in the Tibetan Plateau. Eur. J. Soil Biol., 78: 7 - 16. DOI: 10.1016/j.ejsobi.2016.11.001

JIANG, D.M., LI, Q., LIU, F.M., JIANG, Y., LIANG, W.J. (2007): Vertical distribution of soil nematodes in an age sequence of Caragana microphylla plantations in the Horqin Sandy Land, Northeast China. Ecol. Res., 22(1): 49 - 56. DOI: 10.1007/s11284-006-0187-5

KHAN, Z., KIm, Y.H. (2007): A reviews on the role of predatory soil nematodes in the biological control of plant parasitic nematodes. Appl. Soil Ecol., 35(2): 370 - 379. DOI: 10.1016/j.apsoil.2006.07.007

LI, N., PAN, F.J., Han, X.Z., ZHAng, B. (2016): Development of soil food web of microbes and nematodes under different agricultural practices during the early stage of pedogenesis of a Mollisol. Soil Biol. Biochem., 98: 208 - 216. DOI: 10.1016/j.soilbio.2016.04.011 LI, Q., JIANG, Y., LIANG, W.J., LOU, Y.L., Zhang, E.P., LIANG, C.H. (2010): Long-term effect of fertility management on the soil nematode community in vegetable production under greenhouse conditions. Appl. Soil Ecol., 46(1): 111 - 118. DOI: 10.1016/j.apsoil.2010.06.016 
Liang, W.J., Lou, Y.L., LI, Q., Zhong, S., Zhang, X.K., Wang, J.K. (2009): Nematode faunal response to long-term application of nitrogen fertilizer and organic manure in Northeast China. Soil Biol. Biochem., 41(5): 883 - 890. DOI: 10.1016/j.soilbio.2008.06.018 Lu, R.K. (1999): Methods of Soil and Agricultural Chemistry (in Chinese). China Agriculture Science and Technology Press, Beijing. Lü, Y., Bal, W., Wang, X.F., CAl, Q., Liang, W.J. (2017): Responses of soil micro-food web to land use change from upland to paddy fields with different years of rice cultivation. Pedosphere, 27(1): 155 - 164. DOI: 10.1016/S1002-0160(15)60102-3

MAL, W.F., Lyon, H.H. (1975): Pictorial key to genera of pant-parasitic nematodes. Cornell University Press. Ithaca \& London. pp $1-219$

Mandal, A., Patra, A.K., Singh, D., Swarup, A., Masto, R.E. (2007): Effect of long-term application of manure and fertilizer on biological and biochemical activities in soil during crop development stages. Bioresource Technol., 98(18): 3585 - 3592. DOI: 535 10.1016/j. biortech.2006.11.027

McSoRLEY, R., GALlAHER, R.N. (1997): Effect of compost and maize cultivars on plant-parasitic nematodes. J. Nematol., 29(4S): 731 $-736$

Miao, Y.X., Stewart, B.A., Zhang, F.S. (2011): Long-term experiments for sustainable nutrient management in China. A review. Agron. Sustain. Dev., 31(2): 397 -414. DOI: 10.1051/agro/2010034 MiLES, R.J., BRown, J.R. (2011): The sanborn field experiment: implications for long-term soil organic carbon levels. Agron. J., 103(1): 268 - 278. DOI: 10.2134/agronj2010.0221s

NeHER, D.A. (2001): Role of nematodes in soil health and their use as indicators. J Nematol, 33(4): $161-168$

Olsen, R.S., Cole, V.C., Watanabey, F.S., Dean, L.A. (1954): Estimation of available phosphorus in soils by extraction with sodium bicarbonate. US Department of Agricultural Circulation, pp. 939

Ou, W., Liang, W.J., Jiang, Y., LI, Q., Wen, D.Z. (2005): Vertical distribution of soil nematodes under different land use types in an aquic brown soil. Pedobiologia, 49(2): 139 - 148. DOI: 10.1016/j. pedobi.2004.10.001

Pan, F.J., LI, N., Zou, W.X., Han, X.Z., Mclaughlin, N.B. (2016): Soil nematode community structure and metabolic footprint in the early pedogenesis of a Mollisol. Eur. J. Soil Biol., 77: 17 - 25. DOI: 10.1016/j.ejsobi.2016.09.004

Peterson, G.A., Lyon, D.J., Fenster, C.R. (2012): Valuing longterm field experiments: quantifying the scientific contribution of a long-term tillage experiment. Soil Sci. Soc. Am. J., 76(3): 757 765. DOI: 10.2136/sssaj2011.0413

Porazinska, D.L., Duncan, L.W., McSorley, R., Graham, J.H. (1999): Nematode communities as indicators of status and processes of a soil ecosystem influenced by agricultural management practices. Appl. Soil Ecol., 13(1): 69 - 86. DOI: 10.1016/S09291393(99)00018-9

Scharroba, A., Kramer, S., Kandeler, E., Ruess, L. (2016): Spatial and temporal variation of resource allocation in an arable soil drives community structure and biomass of nematodes and their role in the micro-food web. Pedobiologia, 59(3): 111 - 120. DOI: 10.1016/j.pedobi.2016.03.005

Singh, J., Brar, B.S., SeKhon, B.S., Mavi, M.S., Singh, G., KaUR, G. (2016). Impact of long-term phosphorous fertilization on Olsen-P and grain yields in maize-wheat cropping sequence. Nutr. Cycl. Agroecosys., 106(2): 157 - 168. DOI: 10.1007/s10705-016-9796-8 Steel, H., FerrIS, H. (2016): Soil nematode assemblages indicate the potential for biological regulation of pest species. Acta Oecol., 73: 87 - 96. DOI: 10.1016/j.actao.2016.03.004

Villenave, C., Bongers, T., Ekschmitt, K., Fernandes, P., Oliver, R. (2003): Changes in nematode communities after manuring in millet fields in Senegal. Nematology, 5(3): 351 - 358. DOI: $10.1163 / 156854103769224340$

Villenave, C., Ekschmitt, K., Nazaret, S. \& Bongers, T. (2004): Interactions between nematodes and microbial communities in a tropical soil following manipulation of the soil food web. Soil Biol Biochem, 36(12): 2033 - 2043. DOI: 10.1016/j.soilbio.2004.05.022 Villenave, C., Saj, S., Pablo, A.L., Sall, S., Duigal, D., Chotte, J.L., BonzI, M. (2010): Influence of long-term organic and mineral fertilization on soil nematofauna when growing Sorghum bicolor in Burkina Faso. Biol. Fert. Soils, 46: 659-670. DOI: 10.1007/s00374010-0471-y

Wang, K.H., McSorley, R., Marshall, A., Gallaher, R.N. (2006): Influence of organic Crotalaria juncea hay and ammonium nitrate fertilizers on soil nematode communities. Appl. Soil Ecol. 31(3), 186 - 198. DOI: 10.1016/j.apsoil.2005.06.006

Wei, W.L., Yan, Y., CaO, J., Christie, P., Zhang, F.S., Fan, M.S. (2016): Effects of combined application of organic amendments and fertilizers on crop yield and soil organic matter: An integrated analysis of long-term experiments. Agr. Ecosysyst. Environ., 225: 86 - 92. DOI: 10.1016/j.agee.2016.04.004

Yeates, G.W., Bongers, T., De Goede, R.G.M., Freckman, D.W., GEORGIEVA, S.S. (1993): Feeding habits in soil nematode families and genera - an outline for ecologists. J Nematol, 25(3): 315 - 331 YING, W.Y. (1998): Pictorial keys to soil animals of China. Beijing: China Science Press, pp 51 - 89.

Zhang, Q., Liang, G., Zhou, W., Sun, J., Wang, X., He, P. (2016): Fatty-acid profiles and enzyme activities in soil particle-size fractions under long-term fertilization. Soil Sci. Soc. Am. J., 80(1): 97 - 111. DOI: 10.2136/sssaj2015.07.0255

Zhang, X.K., Ferris, W., Mitchell, J., Liang, W.J. (2017a): Ecosystem services of the soil food web after long-term application of agricultural management practices. Soil Biol. Biochem., 111: 36 - 43. DOI: 10.1016/j.soilbio.2017.03.017

Zhang, X.K., LI, Q., Zhu, A.N., Liang, W.J., Zhang, J.B., Steinberger, Y. (2012): Effects of tillage and residue management on soil nematode communities in North China. Ecol Indic, 13(1): 75 - 81. DOI: 10.1016/j.ecolind.2011.05.009

ZhaO, J., Lı, D.J., Fu, S.L., He, X.Y., Fu, Z.Y., Zhang, W., Wang, K.L. (2016): Using the biomasses of soil nematode taxa as weighting factors for assessing soil food web conditions. Ecol Indic, 60: 310 - 316. DOI: 10.1016/j.ecolind.2015.06.003 
Zhang, Q., Liang, G.Q., Myrold, D.D., Zhou, W.W. (2017b): Variable responses of ammonia oxidizers across soil particle-size fractions affect nitrification in a long-term fertilizer experiment. Soil Biol. Biochem., 105: 25 - 36. DOI: 10.1016/j.soilbio.2016.11.005
ZHong, S., Zeng H.C., Jin, Z.Q. (2017): Influences of different tillage and residue management systems on soil nematode community composition and diversity in the tropics. Soil Biol. Biochem., 107: 234 - 243. DOI: 10.1016/j.soilbio.2017.01.007 